\title{
Positions, Dispositions and Practices in Education Policy in Central and South East Europe (research in progress)
}

ŽIva Kos Kecojević ${ }^{\star 1}$ AND Slavko GabeR ${ }^{2}$

$\approx$ In the article, we present the conceptualisation and selected results of ongoing research dealing with the particular area of top decision making in education in Central and South East Europe. Aiming at a Bourdieuian type of objectification of key agents of decision making in education - ministers - a group of researchers from the region is in the process of interviewing former ministers of education. The interviews should serve as a (frequently omitted) part of the material for a structured analysis of education policy in the region in the times of transition, transformation and metamorphoses in education.

Keywords: Central and South East Europe Decision making, Dispositions, Education policy, Ministers, Positions 


\section{Položaji, dispozicije in prakse edukacijskih politik v osrednji in jugovzhodni Evropi (raziskava v teku)}

ŽIva Kos KecoJević* IN SLAvko Gaber

○ V prispevku so predstavljeni konceptualizacija in izbrani izsledki raziskave, ki še poteka. Osrednja problematika je specifično področje vrhovnega odločanja na področju izobraževanja v osrednji in jugovzhodni Evropi. $\mathrm{Z}$ bourdiejevskim tipom argumentiranja bodo analizirani intervjuji $\mathrm{s}$ ključnimi akterji, ki sprejemajo odločitve na področju izobraževanja ministri. Skupina raziskovalcev je v fazi intervjuvanja nekdanjih ministrov za izobraževanje. Intervjuje bodo uporabili kot (pogosto izpuščen) del gradiva za strukturirano analizo edukacijskih politik v regiji med tranzicijo, transformacijo in preobrazbo v izobraževanju.

Ključne besede: dispozicije, edukacijske politike, ministri, odločanje, osrednja in jugovzhodna Evropa, položaji 
One of the main focuses of the CEPS Journal, as well as of the CEPS,${ }^{3}$ is to conceptualise education policy in Central and South East Europe (CSEE).

In line with our orientation, and in cooperation with experts ${ }^{4}$ from the region, we have launched specific and focused research on top decision making in education in the region, and we present here the first insights provided by this work in progress. For the research, we plan to cover 5-8 countries in CSEE with structured interviews with former ministers of education. The interviewees should be ministers from the period after 1989 who have not held office in the last four years.

The interviews should, if possible, be carried out by national experts from the field of education policy studies. An invitation letter was drafted in autumn 2011 and sent to identified potential collaborators in the region. In this letter to the experts, we wrote that with the interviews "we aim at:

- Snapshots (representative - important ministers, mainly longstanding in office, from different countries, the same region...) of socio-analyses in policymaking and politics in education during last 20 years in the region(s) of Central and South East Europe

- Insights into:

- The conceptualisation of education policy in last 20 years in the particular nation at the systemic level thorough the eyes of the top policymakers

- Such insights should be complementary to expert insights from the same country (...)

- Their social and political background

- Their professional educational background

- Their type(s) of rationality (how they perceive society and education in society, which mechanism they conceptualise and use in policymaking);

- how they perceive politics and its role in it..." (cf. Invitation, 2011)

For the methodology, we decided to primarily follow the "Bourdieu approach in La misere du mond. We would like to acquire the personal opinions of the participating ministers and combine their insights and those of experts into

3 Cf. CEPS homepage for research (http://ceps.pef.uni-lj.si) and the CEPS Journal mission statement (http://www.cepsj.si/doku.php?id=en:cepsj).

4 The first interview was made with the former Austrian minister, and was conducted by C. Gepperd and S. Bauer. The second was made with the former minister from Montenegro, and was conducted by S. Gaber. The third interview was with the former Serbian minister, and was conducted by I. Jarić, while the fourth interview, with the former Slovenian minister, was undertaken by Ž. Kos Kecojević. 
the "social weight" involved in their conceptions of politics, policy, education and their implementation of the proposed and inaugurated changes in education in last 20 years" (cf. Invitation, 2011).

After preparing the first draft of the structure of the interview and sending it for comment and improvement to the experts interested in collaboration, we commenced the interviews in some of the CSEE countries. Interviews with former ministers from Austria, Montenegro, Serbia and Slovenia have already taken place, while interviews with ministers from Hungary and Croatia have been arranged for the autumn. Our plan is to compare the reflections of the former ministers with the state of the art in national education (today and at the beginning of the 1990s), investigating their conception and perception of social partner engagement in education reforms, their attitude towards international comparative studies, etc. As mentioned above, we are still in the research process, and we therefore present here only parts of the interviews that we have performed thus far with former ministers of education in Central and South East Europe.

The ministers selected were members of governments in the times of "great transformation" and/or metamorphoses in Europe (with regard to these concepts, compare Polanyi (1944) and Castel (1995)) and, in the majority of cases, also in their respective countries (Serbia, Montenegro, Slovenia and Austria).

The interviews were conceptualised and carried out with close reference to the Bourdieuian approach to the object formation of research. In particular, we try, also in the interpretation, to follow examples of his work and the work of his group on the objectification of the "weight of the world"' (cf. Bourdieu, 1993, 1998). Using the aforementioned research as guidance, we aim to establish the first outlines of an understanding of the positions and dispositions of particular nations in the region, and through these gain an insight into their constructed education policies (practices).

We perceive the Bourdieuian approach as productive and enabling an understanding of political moves (practices) not primarily as heroic or corrupt political acts of individuals who stand as more or less moral individuals, but more as practices of agents who acted in a particular social space (field) structured by dispositions and positions that narrowed the imagined scope of the

5 "But how can we offer readers the means of understanding - which means taking people as they are - except by providing the theoretical instruments that let us see these lives as necessary through a systematic search for the causes and reasons they have for being what they are?" /.../ "These benchmarks and observations recall the social conditions and conditionings of the men and women talking, along with their careers, education and work experiences - everything that is at once hidden and disclosed, ..." (Bourdieu, 1998, pp. 1-2). 
free manoeuvring of each of them, without eliminating their responsibility for actions. ${ }^{6}$ With the aforementioned conceptual point of departure, and in the process of further elaboration (contextualisation) of the interviewed policymaking agents (ministers) and their politics, we hope that their perceptions and actions will become more transparent and, within the given period of time, also more intelligible (cf. Bourdieu, 1998, p. 625). We see this dynamic as dependent on the structures of different fields (from political and social to educational), as well as on the function of the embedded dispositions in the habitus of the ministers (cf. Bourdieu, 1988, 1992).

As mentioned above, experts from different countries in the region conducted interviews in which ministers presented their reflections on society, education, politics and their involvement in education policymaking in a particular period. Their reflections on society, values and fiercely discussed topics in education, as well as their deliberations on their own family and educational background, have one overall aim: to provide insights into the processes of policymaking in the field of education. The relatively rich material that we have collected thus far is ready for further research and will be supplemented with similar interviews from certain other countries in the region by the end of 2012.

We believe that the analyses that will follow next year will enable us to gain additional insights into how decisions in education policy in the countries of Central and South East Europe have been structured, conditioned and performed. Systematically searching for the context, the constellation of power relations, in the field of policymaking in a concrete nation and reflecting the objectified decision makers' "personalities" - attitudes, cultural capital, professional dispositions, family background - we add to insights into the process of education reforms in the last 20 years (cf. Bourdieu, 1988, 1992).

Such an approach enables us to avoid arriving at the study of education policy/politics through dyads of great/disastrous and heroic/corrupt politicians, and gives us an opportunity to reach beyond the opposition of neoliberal $v s$ social welfare education policy and politics. It also invites the search for an understanding of reciprocities of dependence, repression and enabling as integral parts of political practices of the past decades. We suggest reading the presented selection of answers from the interviews as initial insights (for the time being lacking appropriate contextualisation) into the positions, dispositions, fields and habitus of the agents we have started to analyse.

6 "A greater understanding of the mechanisms which govern the (...) world should not have the effect of releasing the individual from the embarrassing burden of moral responsibility (...). On the contrary, it should teach him to place his responsibilities where his liberties are really situated (...)" (Bourdieu, 1988, p. 4). 


\section{Snapshots of positions for dispositions ${ }^{7}$}

1. Family cultural capital as a background for their own cultural capital

The Austrian (AT) minister:

".../my mother was a kindergarten teacher and a very good pianist and singer, my father was the director of a paper mill, and my grandfather was a painter."

The Montenegrin (ME) minister:

"My father graduated in philosophy - the Faculty of Humanities, Department of Philosophy /.../. For a certain period, he was a teacher in upper secondary education; for the rest of the time, he was a party official with various duties. My mother gained a lower secondary diploma. She practically took care for four kids and was for a certain period employed as a person dealing with basic finances."

The Serbian (RS) minister:

".../my father graduated from the Faculty of Economics and my mother gained an upper secondary diploma. He was an economist at the Official Gazette of SFRY and my mother was a public employee in a national accountancy agency. ${ }^{8}$ She is from Belgrade and he is Hercegovac. I was born in Belgrade. My grandmother (on my mother's side) is also from Belgrade, so taking into the account this line I am a native of Belgrade."

The Slovenian (SI) minister:

"By origin, I am from a simple workers' family. My mother never worked, my father was a driver. Yet in our house knowledge was highly valued. My mother in particular wanted an education for her children, and that is why we are all educated. Two out of four gained a PhD, and I believe that the kind of family you are from is not that important; more important is the attitude of your family to knowledge, to the progress and development of the children. It is, of course, easier if the family culture is higher, but not always."

7 While trying to capture the "double reality of social world", Bourdieu "weaves together a 'structuralist' and 'constructivist' approach. First (...) to construct the objective structures (spaces of positions) (...) that define external constraints (...). Second, we reintroduce the immediate, lived experience of agents in order to explicate the categories of perception and appreciation (dispositions) that structure their action from inside." (Bourdieu \& Wacquant, 1992, p. 11).

8 National Accountant Agency, better known as SDK. In the former socialist system it was the proxy of what is today tax administration. 
2. Education as the path to embedded and institutionalised cultural capital

The AT minister on her education:

"I was simply an elementary school teacher: elementary school, lower secondary school teacher training college. At that time, it was called teachers' training college. /.../ I was always involved in teaching. I was with the boy scouts and the girl guides for 10, 20 years. /.../ But I liked going to school, especially to teacher training college, and my favourite subjects were mathematics and latin. /../ I was always inclined towards music. I learned the flute and the piano, and I always felt that music education was incredibly important."

On the differences between her education and that of today:

"I think that the education system of today has become much more diverse. There wasn't the variety in my time. /.../ the differences are quite enormous. There has been an upgrading in all areas. A lot of what once was normal school is now at college level and university level./.../ This strong upgrading has been accompanied by an "academisation" of various professions. I can't judge if this is positive or not. /.../ Something else that has changed significantly is all the effort and the mass of books children have today. /.../ The desire of parents to get their children into higher education has become very strong. Happiness today often depends on whether or not the child graduates. /.../Ability comes from practice and repetition; it doesn't come from intellectual explanations./... That has changed dramatically. I think today children are often overburdened at school, because they really should be practising. You have to practice your whole life."

The ME minister presenting his education:

"My primary education" took place in Nikšicis", and after that secondary education in a 'gimnazija'. I moved to Belgrade and graduated in physics there. My first job was as a teacher at a 'gimnazija' in Nikšić. Then I went to the army, after which I got a research job at the Institute for Physics in Belgrade. At the same time, I was assistant at the faculties of mathematics and pharmacy. In 1976, I earned a master's degree and went to Russia, to the institute in Dubna. ${ }^{11} / . . /$ By chance, I was a member of a group researching collisions of particles, and in

9 For all the ministers from former Yugoslavia, primary education is the equivalent of comprehensive primary and lower secondary and obligatory education.

10 Nikšić is the second largest city in Montenegro. The capital of Montenegro is Podgorica.

11 The Dubna Institute for Nuclear research was established in 1956 on the basis of two research institutes of the USSR Academy of Sciences: the Institute for Nuclear Problems and the Electro Physical Laboratory. The Institute has seven laboratories, each with its own specialisation: theoretical physics, high energy physics (particle physics), heavy ion physics, condensed matter physics, nuclear reactions, neutron physics, and information technology. The Institute has a division for studying radiation and radiobiological research, as well as other ad hoc experimental physics experiments (more: http://www.jinr.ru/). 
Russia they had developed a new technique of research using nuclear emulsions in so-called bubble chambers. So I went to Dubna on a stipend and stayed there for two and a half years. I published there - I believe I published six articles, which I combined into a logical whole in my PhD /.../. After two years, I came back in Belgrade, where I received my PhD in 1979. /.../ After my PhD, a group of people were lobbying for a new science-maths faculty in Podgorica and they persuaded me to join." ${ }^{\prime 2}$

Concerning the differences between education in the time of his schooling and today, he states:

"Then, a strong collectivist spirit was present, solidarity existed, feeling for the other. In one word, values existed that bit by bit disappeared later. Upper secondary education was demanding /.../ but after it we were ready to be successful students, and I had no problem studying in Belgrade."

The RS minister described his education as typical for a Belgrade child:

"All of the schools I attended here are in a one kilometre radius, as I am more or less in the centre of the city. I went to Holland twice to undertake my specialisation at the Centre for International Studies, but that was after I graduated from university. I managed to prepare a lot of material for my masters as well as my doctorial studies there /.../. All of the rest in an educational sense is connected to Serbia, that is, Former Yugoslavia./.../ In that time, I attended V. Belgrade gimnazija - probably the best one in Belgrade."

Q: "You graduated from the Belgrade Faculty of Law?"

"Yes, and finished my masters and doctoral studies there as well."

Comparing his education and education today, he states:

"This question is quite complicated, because my perception of education is better than that of a regular citizen, and so the answer could be quite comprehensive. There are a lot of differences on the systemic level that prevent an easy answer. I am not fond of generalisations that come down to "it was better in my time, my schooling was better". I don't like that because it isn't true. There is something distinctive about every time period. This is mostly due to differences on the level of the system. /.../ Unfortunately, I think that there still exists relatively strong continuity in relation to the old education. Roughly speaking, it comes down to the

12 As one of the smallest republics in former Yugoslavia, Montenegro opened its own university (1976) with studies only in economics, law and technical studies, joined by education and nautical academies, as well as two institutes - for agriculture and biology and medicine. The minister is thus describing his academic trajectory, which reflects the state of university education in his nation, as well as Montenegro's dependence on Serbian higher education. The first moves towards independent higher education, as part of Montenegro's path to becoming an independent state (independence was declared on 3 June 2006), were consolidated during the time that he was a minister in the newly established state. 
notion of curriculum. I don't think any systemic cuts in the curriculum have been made since I was at school. /.../ The second factor is human resources, which are the most difficult to shift, and the philosophy of our teachers, professors, lecturers /.../has remained the same. So we don't have highly developed pedagogicalpsychological or methodological capacities of primary, secondary or university teachers. I.../ Sadly, if I estimate whether continuity exists, my answer would be yes, but that isn't the best feature."

The SI minister on her education:

"I was very good in languages and I enrolled to study Italian and French, graduating as a teacher of both. Then I went into practice and was a teacher at a 'gimanzija' for 10 years."

After her masters, and due to the transformation of teacher academies into faculties, she decided to undertake doctoral studies in the field of education sciences, gaining her $\mathrm{PhD}$ in multi-linguistics. Comparing her education with the state of the art in education today, she states:

"In Slovenia, we still stress the amount of knowledge; that hasn't changed. /.../ I observed the same old pattern in the time of the education of my two sons and my much younger daughter. Another characteristic is that we are still inclined towards general knowledge."

Firstly, we can observe that the ministers, all members of the post-war upward mobility generation, mainly achieved a level of education that is higher than that of their parents (three out of four even gained a $\mathrm{PhD}$ ). Some of them perceive education today as different from education in the time of their schooling, with some seeing too much of an old approach to education in their countries. None of them attended private education and, with the exception of the Montenegrin minister, they graduated from the broad area of social sciences or humanities.

\section{Cultural capital, positions (employment positions and functions) as dispositions for education policymaking}

1. From prior employment (position) to the post of minister

The AT minister:

"Yes, before I was a teacher, an elementary school teacher. I was always involved in teaching./... I was obviously very close to the whole education sector. No one could fool me. I knew how things went. I had already been in the provincial government in Vorarlberg. I had a funny portfolio: development aid, energy conservation, women." 
The ME minister:

".../ I was part of the team preparing education reforms that were to follow /.../ so before becoming minister I was involved in considerations about possible and needed changes in education, which helped me /.../. It was easier to enter the cabinet and it enabled me to implement what we considered necessary. /.../ In any case, I was a minister who didn't come from politics to the cabinet /.../ I came as someone knowing the field, knowing what we should do. It was to my advantage that I was close to the sources of information, that I was part of the process. /.../ As I had spent my whole life in education, I had an idea about education - how it works, about procedures, what to change. At the faculty, I had been in charge of the department, I had been the dean, and at the level of university also the vice rector."

The RS minister:

"It was a career cut. /.../ At that moment, I was aware that I was leaving the space of law and entering the space of education, and that suited me well. My pedagogical career began in 1980. That means I had been in education for 20 years, my notion of it was beyond self-evaluation. What might be connected to the question is the fact that I entered the education system as a teacher with no prior methodological, pedagogical, sociological or psychological education about what was going to be my work./.../ Yes, I think I was a member of the main committee /.../. I also think that I was vice president of the party, but in any case a member of the party's leadership. Those are the main functions of every party."

The SI minster:

".../I took on the ministry in a field that I was familiar with. I think that a minister who comes, let's say, from the field of law and takes over the Department of Transportation, or a minister from the field of transportation who takes over the Department of Education, is partly reasonable, because he is a politician and knows all the dangers of politics, but on the other hand, he can have serious problems due to a lack of professional knowledge. For that reason, I think, because I already passed from teacher to consultant and university teacher. /.../ Basically, I relied on my strategic competences, that is, I had a feeling that in a decisive moment I would have no problems. I know how to organise myself, how to get others to tell me, help me, consult with me and then make a decision."

Related to the shift in positions, all of the ministers had had prior experience in the field of education. On the other hand, none of them had been professionally trained, educated to deal with education as a social sub-system. Two of them had also had experience in consultative and managerial positions. None of them had had prior leading political functions; one of them had never 
been a member of any political party, and was not even a member during the time of his mandate.

\section{Positions and dispositions in practice}

1. The main reforms during the time of the ministers' mandates

The AT minister: (mandate 1995-2007) discusses important changes in her eyes:

"What was also very important for me personally, and later as a politician, was to educate people into being practical persons who can recognise their individual abilities and be proud of them, because everyone is different. /.../ And secondly, you have to dare: dare to do something and dare to decide something. To decide is always to assume responsibility. I've seen this so many times./.../ That's why I always wanted to have independent schools that can decide a lot of the things themselves, just with a framework./.../ Autonomy means that I have a framework, but autonomy doesn't mean that everyone can do what they like. /.../ And another important development was specialisation in technical fields, and also in the business administration sector. This means that higher educational institutions like technical and business colleges have amazing new specialised areas because of automation and computerisation. We also gave the general secondary and the academic lower secondary level the opportunity to choose priorities, like focusing on the artistic or creative side or any other direction. /.../ Through the reforms, I wanted schools to have more autonomy, so as to be able to set priorities themselves and then choose. But I've noticed that this is not popular at all. /.../ PISA was a big issue. Then the reduction of hours. That developed its own momentum. This momentum was cruel. Then the university reform. That was madness. Just a huge challenge. /.../ I tried to implement this hundred per cent permeability, with the possibility of changing after four years of lower secondary (now it's called new middle school) directly into the senior classes (upper secondary). But to do this you have to differentiate. In the eyes of those who think that everyone has to reach the average, differentiation is the devil's handiwork. They always say segregation and exclusion. /.../ I introduced tuition fees, five thousand Schillings, and for those who weren't able to pay there was an opportunity to apply for a bank loan at a zero interest rate: I paid two percent interest and the bank paid the five thousand Schillings directly to the university. /... We didn't have a drop in student numbers. It eliminated many inactive enrolments that had be there otherwise, so I'm all for it, but with social cushioning, of course." 
The ME minister: (mandate 2003-2008) presented the main changes of his mandate:

"That means changes in education programmes, that is, textbooks, different organisation of primary schools, on the level of the system - therefore the institutional formation of the system - the appearance of new institutions that deal with professional matters, external quality assessment, matura, computerisation of schools is also important, as well as drastic improvement of school infrastructure. /.../ equalisation of formal and non-formal education."

"You have to be aware of the fact that the education system had established a unique informational base that no other system in Montenegro has. This base, unfortunately not used much these days, contains information about all employees, students, all of the infrastructure - you can get an overview of all of the grades from whichever subject for a particular student. Various analyses can be made that could help the system to improve and develop. /.../ We in the Department of Education knew exactly how many teachers were due for retirement when and in which subject. We were able to plan for, let's say, five years ahead how many maths teachers would be needed. I see this is not used a lot nowadays."

The RS minister: (mandate 2000-2004) about principles and changes during his mandate: ${ }^{13}$

"I can say that we spent two years convincing the system that another way exists. Then we tried to implement changes, we passed a great Systems Act, which I personally think is good. Only then did the system begin to function a bit."

"I will try to determine five reformative aspects we aimed to follow. One of them was definitely egalitarian education. Equal access to education and equal opportunity in relation to what society can offer. The second was a change in the way schools were being managed. Management on the school level aimed at making schools more open in relation to stakeholders, whom we tried to find in parents and local community. The third was the change in curriculum, the reduction of the central curriculum and the increased autonomy of schools or areas of autonomous project planning, that is, $10 \%$ for lower classes and up to $30 \%$ by the fourth year of high school. In any case, increasing autonomy of schools. Raising the question of children's rights was seen as a mechanism through which the teacher-student relationship could be shifted. This always came back to us like a boomerang, with claims that we were actually protecting the children and not the system that we needed to run. This was a consequence of our position. A balance needs to be found. An attempt to reform those subjects that hold educational

13 Compare his words with the analysis of the same period in the Pešikan \& Ivić article in the present edition of CEPS Journal. 
means, by this I primarily mean textbooks. Exposing publishers to competitiveness and the choice of what a textbook should be on the level of the local community. We managed to establish all of the procedures. It took a lot of time to establish the system. We established all of the procedures from nothing, all of the standards the system never had."

The SI minister: (mandate 2000-2002) about important challenges and achievements during her term in the cabinet:

"In the field of compulsory schooling, I can say we slightly regulated external examinations. External examination was sort of a problem, a kind of challenge that could not be neglected, as were school districts for primary education. There was a significant tendency towards a reduction of school districts, which escalated during our government. We fought for every single school. I visited I don't remember how many schools - the smallest, the highest compulsory school in Slovenia, in short, every boutique example - and found out how precious they were for the local community and what they offered, how committed and engaged the teachers in these schools were /.../ we fought against reduction there and at the level of secondary schools as well. At the level of secondary school, in that time, it was obvious that a change of curriculum was needed, and we started to change the core curriculum to modular. The first modules were attempted in technical and vocational schools, where it was impossible to educate a whole group of cobblers, mechanics, etc., with this basic knowledge as a kind of 'stadium generale', as well as the modules. There was a lot of work invested in that./... In the field of higher education, it was a time that demanded consideration of whether and how to privatise the sector. This had already been initiated by my predecessor and it continued with "how many" more universities in Slovenia and "how". /.../Financing took a lot of our time, which was very interesting. We couldn't pass the Financing of Higher Education Act, which was similar to the acts that had been passed for all other levels. /.../ But there was a kind of a breakthrough in the field of science, the cooperation with the Minister of the Economy was very good. We managed to pass the first modern law, which hasn't changed much since, the Research Activity Act. With it, the economy got research groups, programme groups. Young researchers ${ }^{14}$ in the field of economics already existed, but that was not functioning well. There was another problem that still persists today: religious education in public schools. I remember the Vatican Treaty was made in that time and the Prime Minister wanted some kind of a solution. He asked me several times whether I had any kind of model enabling us to keep public schools secular and still cater for the possibility of religions being respected and the possibility of learning about them in schools."

14 More about young researchers: http://www.arrs.gov.si/en/mr/index.asp. 


\section{Conclusion}

As we can see in the last section of our presentation, all of the ministers - who have different family and educational backgrounds, and their own individual previous work experience - conceptualised, and to varying degrees implemented, changes in education after taking over the post of minister. During the interviews, the experts also asked questions related to unrealised reforms, as well as their relation with stakeholders and groups supporting or opposing their intended or implemented reforms. In our base of interviews, we also have the ministers' answers concerning their attitude towards religious instruction, private $v s$ public education, the role of parents in education, the Bologna process, the relationship between education and employment, etc. All of the answers are waiting for interpretation and further elaboration, which will take place after a few more interviews in autumn this year.

\section{References and sources}

Bourdieu, P. (1988). Homo academicus. Stanford: University Press.

Bourdieu, P., \& Wacquant, L. J. D. (1992). An invitation to reflexive sociology. Chicago: The University of Chicago Press.

Bourdieu, P., et al. (1993). La misere du monde. Paris: Editions du Seuil.

Bourdieu, P., et al. (1998). The weight of the world. Social suffering in contemporary society. Stanford:

University Press.

Castel, R. (1995). Métamorphoses de la guestion social. Paris: Galimard.

CEPS homepage for research (http://ceps.pef.uni-lj.si)

CEPS Journal mission statement (http://www.cepsj.si/doku.php?id=en:cepsj)

Interviews with the ministers of Austria, Slovenia, Serbia and Monte Negro. (recordings)

Invitation (2011). Invitation to collaboration (letter conceptualised and revised by S. Gaber, P. Zgaga

and Ž. Kos Kecojević).

Joint institute for nuclear research: http://www.jinr.ru/ (4.6.2012)

Polanyi, K. (1944). The Great Transformation. New York, Toronto: Farrar \& Rinehart.

Young researchers: http://www.arrs.gov.si/en/mr/index.asp (4.6.2012) 


\section{Biographical note}

Živa Kos Kecojević is a doctorial student of Teacher education and educational studies at the Faculty of Education, University of Ljubljana. Her research priority is Quality assessement and assurance.

SLAVko GABER is associate professor of the Sociology of Education at the University of Ljubljana. His research areas are educational policy, equity and equality and quality in education. 